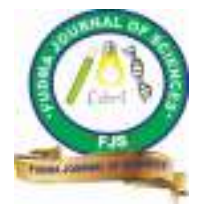

FUDMA Journal of Sciences (FJS)

ISSN online: $2616-1370$

ISSN print: 2645 - 2944

Vol. 4 No. 3, September, 2020, pp $10-16$

DOI: https://doi.org/10.33003/fjs-2020-0403-344

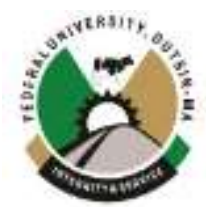

\title{
EXAMINING THE PROCESS OF DECOMPOSITION AND CARBON CYCLING IN 'FADAMA' COASTAL WETLANDS: A CASE STUDY OF HEAPING WETLANDS ECOSYSTEM
}

\author{
${ }^{* 1}$ Dasat, G. S., ${ }^{2}$ Danjuma, G., ${ }^{2}$ Chundusu, E. S. \\ ${ }^{1}$ Department of Food Science Technology, \\ ${ }^{2}$ Department of Science, Plateau State Polytechnic, Barkin Ladi, Plateau State, Nigeria \\ *Corresponding Author's Email: dgsspoly@yahoo.com, 08060885533
}

\begin{abstract}
Wetlands provide several ecosystem services including carbon capture and storage, water filtration, nutrient cycling, and support agriculture among others. The biogeochemical process and decomposition parameters in 'Fadama' wetland soils comprising of Gada biyu, Pwomol and Kpang referred to as sites A, B, and C respectively all of Heipang District in Barkin Ladi, Plateau State was investigated using standard operating procedures (SOP). Results of investigations revealed that soils from Kpang had slightly higher water content (34.52\%) than those from Pwomol (33.48\%) and Gada biyu (32.03\%). While soils from Gada biyu had the highest solid organic matter (SOM) (10.79\%) followed by Pwomol (8.15\%) as Kpang had the least $(7.85 \%)$. Gada biyu soils had the lowest Phenol oxidases activity (1536.56 nmol dicq $\mathrm{g}^{1}{ }^{1} \mathrm{~h}^{-1}$ ) while those from Pwomol (5340.44 nmol dicq g- $\left.{ }^{1} \mathrm{~h}^{-1}\right)$ was highest. All sites had similar concentrations of soil phenolics $(76.58$ $\mu \mathrm{g} \mathrm{g-}{ }^{1}, 79.98 \mu \mathrm{g} \mathrm{g-}^{1}$, and $\left.83.25 \mu \mathrm{g} \mathrm{g}^{1}\right)$. The activity of hydrolyses ( $\beta$-glucosidase) in Gada biyu soil (2.93 nmol g- $\left.{ }^{1} \mathrm{~min}^{-1}\right)$ was lower than those from Pwomol $\left(6.13 \mathrm{nmol} \mathrm{g-}{ }^{1} \mathrm{~min}^{-1}\right)$. These parameters indicate the level of biogeochemical processes in the soil at each site. Gada biyu had the highest rate of $\mathrm{CH}_{4}(0.84 \mathrm{ug}$ ${ }^{1} \mathrm{~h}^{-1}$ ) flux. Decomposition of organic matter, carbon cycling and greenhouse gas storage in wetland soil, is due to the anoxic condition comprising of low oxygen availability, cool temperatures, anaerobic conditions, reduced microbial activity, and the quality of organic matter substrates in such soils. Anthropogenic disturbances affecting wetlands must be discouraged to promote vital ecosystem services.
\end{abstract}

Keywords: Wetland, Carbon, Sequestration, Enzyme activity, Decomposition.

\section{INTRODUCTION}

Wetlands are biologically complex environments due to the biogeochemical and physical processes associated with such soil settings (Mitsch \& Gosselink, 2015). Wetlands are therefore one of the world's most valuable habitat types, due to the numerous ecosystem services they provide, including water filtration, protection from coastal erosion, soils for agriculture purpose, supporting biodiversity, fishing for food and economy, trees for various purposes and carbon sequestration (Shange $e t$ al., 2013; Mitsch \& Gosselink, 2015; Adame \& Fry, 2016).

The unique soil property of waterlogging places a constraint on the breakdown of organic matter, thereby promoting the sequestration and burial of carbon as sediments, making these ecosystems valuable tools against climate change (Freeman et al., 2001, Adame \& Fry, 2016). Thus, carbon sequestration is the process of confiscating atmospheric carbon dioxide and burying the same as soil sediments (Whiting \& Chanton, 2001; IPCC, 2007, 2014).

The capture and storage of atmospheric $\mathrm{CO}_{2}$ and other greenhouse gases (GHGs) in wetlands soil for a very long period has been encouraged through the build-up of biomass or soil organic matter (Mer \& Roger, 2001). Therefore, wetlands globally account for the storage of up to $500 \mathrm{Pg}$ of soil carbon which is about two-third of total terrestrial soil carbon (Bridgham, et al, 2006, Zheng et al., 2013; Suratman, 2017). This unique condition provides support and nourishment to diverse biodiversities, they also serve as living filters which process pollutants from terrestrial runoffs and atmospheric deposition (Reddy \& De Laune, 2008).

The discharge of sequestered greenhouse gases (GHGs) from wetland soil is due to increased microbial activities which could be attributed to several varying environmental conditions resulting in high decomposition of soil organic matter. Such environmental conditions could include water table, soil texture, presence of atmospheric oxygen, $\mathrm{pH}$, temperature, leaf litter materials, and availability of microbes (Limpens et al., 2008; Kayranli et al., 2010).

Updegraff et al. (2001) posited that several climate change models forecast warmer and drier climatic conditions globally. This scenario could result in a serious water drawdown thereby influencing the biogeochemical processes in the soil resulting in high rates of organic matter decomposition. A dryer atmospheric condition could turn wetlands from carbon sinks into net sources (Freeman et al., 2001). Freeman et al. (2004) conducted both laboratory and field investigations with the outcome suggesting that drier climatic conditions could compromise many wetland biogeochemical processes vital ecosystem services. Mcleod et al. (2011) and Adame et al. (2015) noted that rising level of $\mathrm{CO}_{2}$ in the atmosphere is as a result of increased deforestation which has resulted in degrading vital ecosystem services.

\section{Nigeria's wetlands}

Nigeria is endowed with both coastal and inland wetlands 
ecosystem accounting for about $3 \%$ of the total land area (Nwankwoala, 2012) (These wetlands are mostly found in the Niger River, Benue River, Chad basin and the Niger Delta, with the latter being the most important wetlands in Nigeria, the largest in Africa and third largest area in the world (Ajibola \& Oni, 2015). Furthermore, in Nigeria, wetland comprises inland swamps, mangrove, and freshwater swamps, and shallow to deep water 'fadama' (Zaccheaus 2011). Unfortunately, (Chidi \& Ominigbo, (2010) opined that most of Nigeria's wetland sites are not well documented and gazetted, as only 11 out of over 70 are recognised as Ramsar sites.

Nigeria's wetlands support many biodiversities as they are home to most of the country's endangered species including microbes, plants, insects, amphibians, reptiles, birds, fish, and mammals. Furthermore, Nigeria's wetlands are a very important source of natural resources upon which many rural economies depend (Uluocha \& Okeke, 2004).

The value and resources of Nigeria freshwater wetlands could produce about 510,000 tonnes of fish, support over 14 reptile species, over 70 mammal species, 5 amphibian species, about 72 bird species, and over 200 species of fish. Some of these species especially the birds are endemic to Nigeria (Olalekan et al., 2004).

Despite this importance, Nigeria's wetlands are threatened by both natural and anthropogenic factors such as marine and coastal erosion, desertification, population pressure, urbanization, mining, oil, and industrial waste pollution, uncontrolled agricultural practices, overgrazing, logging, land reclamation and construction of dams. Such anthropogenic activities could release buried ancient GHGs with negative implications for the global atmosphere. These primary GHGs have been implicated with climate change (Malmer et al., 2005; Liikanen et al., 2006; Mander et al., 2008). Nwankwoala, (2012) opined that Nigeria contributes less to the global greenhouse effect, this notwithstanding, the country remains the most vulnerable to the adverse effects of global warming and climate change.

Additionally, (Adewumi \& Ujoh (2012) stated that previous studies on the extent of wetlands in Nigeria indicated that extensive areas of wetland ecosystems are increasingly being wiped and suggested effective management to preserve the same. Similarly, the Lake Chad basin has been identified as a major 'climate catastrophe' which is partly responsible for the current uprising in the West African sub-region, affecting over 10.7 million people.

\section{METHODOLOGY}

\section{Sampling site}

Sampling was performed in January in three wetland sites (Gada biyu, Pwomol and Kpang designated as sites A (0487420 E, $1071830 \mathrm{~N}), \mathrm{B}(0487825 \mathrm{E}, 1067345 \mathrm{~N})$ and C (0494304 E, $1066203 \mathrm{~N})$ respectively in Heipang District of Barkin Ladi LGC, Plateau State.

\section{Sample collection}

Soil samples weighing about $200 \mathrm{~g}$ devoid of unwanted materials were collected from a depth of 10-12 cm in replicates of five with the aid of a trowel and placed in labelled sealed bags and further in cooler boxes containing ice packs. Samples were stored at $4^{\circ} \mathrm{C}$ in the laboratory before analyses within two weeks. Average field soil temperatures were $10^{\circ} \mathrm{C}$ in site $\mathrm{A}$, and $9.5^{\circ} \mathrm{C}$ in sites $\mathrm{B}$ (Pwomol) and $\mathrm{C}$ (Kpang).

\section{Laboratory Analyses}

Soil samples, enzyme substrates, and all reagents used in these analyses were incubated at field temperatures for 24 hours. All laboratory analyses, preparation of enzyme substrates, calibration solutions for phenolics, and other reagents were done according to the procedure described by Box (1983), Frogbrook et al. (2009), and Dunn et al. (2014).

\section{Water Extraction}

A $5 \mathrm{~g}$ subsoil sample was transferred to a $50 \mathrm{ml}$ falcon tube, after which $40 \mathrm{ml}$ deionised water was added and placed on a shaker at $300 \mathrm{rpm}$ for 24 hours. This was followed by centrifuging at $5000 \mathrm{rpm}$ for 30 minutes in a microcentrifuge and $20 \mathrm{ml}$ of sample filtered through $0.45 \mu \mathrm{m}$ cellulose nitrate filters.

\section{Soil Water and Organic Matter Contents (SOM)}

Previously weighed crucibles containing about $10 \mathrm{~g}$ soil samples were placed in an oven at $105^{\circ} \mathrm{C}$ for 24 hours for effective evaporation of water content. After weighing again, crucibles containing the soil were ashed in a muffle furnace for 60 minutes at $550^{\circ} \mathrm{C}$ and weighed thereafter. The weights were used to calculate the water and organic matter contents as a percentage of the original sample using Microsoft Excel spreadsheet.

\section{Phenol Oxidase Enzyme Assay}

Two sets of soil samples weighing $1 \mathrm{~g}$ were placed into two separate stomacher bags labelled blank (B) and substrate (S). Then, $9 \mathrm{ml}$ of deionised water was added, homogenised in a stomacher machine. To the bags labelled $\mathrm{S}, 10 \mathrm{ml}$ of substrate phenolic amino acid L-3, 4-dihydroxyphenylalanine (L-DOPA) solution was added while the same volume of deionised water was added to bags B. All bags were homogenised and incubated at field temperature for 10 minutes.

A set of three $1.5 \mathrm{ml}$ tubes were filled with solutions from each bag and centrifuged at $10000 \mathrm{rpm}$ for 5 minutes. $300 \mu \mathrm{L}$ of the supernatant was pipetted into wells of a clear 96 well microplate and the absorbance determined at $475 \mathrm{~nm}$ using SpectraMaxM2e spectrophotometer plate reader. Soil enzyme activity was thereafter determined and expressed as nmol of product formed.

\section{Hydrolyses}

The activity of soil hydrolyses enzymes was determined by placing $1 \mathrm{~g}$ of the soil sample in labelled stomacher bags, followed by the addition of $7 \mathrm{ml}$ of the relevant substrate solution previously prepared. After analyses was done as for Phenol oxidases above.

\section{Phenolic Assay}

To determine the concentration of soil phenolics, calibration standards of $0,0.25,0.5,0.75,1,2,3 \mathrm{ppm}$ was chosen from the previously prepared phenolic stock solution. For each calibration standard and sample, $1 \mathrm{ml}$ was pipetted into separate labelled $1.5 \mathrm{ml}$ microcentrifuge tubes and $50 \mu \mathrm{l}$ of FolinCiocalteau Phenol Reagent and $0.15 \mathrm{ml}$ of $\mathrm{Na}_{2} \mathrm{CO}_{3}$ solution added to all tubes, mixed and incubated at room temperature for 1 hour 15 minutes, a gradual colour change to blue indicates phenolics presence. Phenolic concentration was determined as for Phenol oxidase assay above. 
Gas Fluxes.

GHGs $\left(\mathrm{CO}_{2}, \mathrm{CH}_{4} \mathrm{~N}_{2} \mathrm{O}\right)$ in the soil were done by placing $10 \mathrm{~g}$ of soil into a $50 \mathrm{ml}$ falcon tube and incubated at field temperature for 1 hour. Gas samples were extracted with $10 \mathrm{ml}$ needle and syringe an analysed on a Varian Model 450 gas Chromatograph (GC) following procedure described by), Frogbrook et al. (2009) and Dunn et al. (2014).

\section{Statistical Analysis}

Data generated were analysed by one-way ANOVA to determine the effect of the measured parameters. SPSS v22 (IBM Corporation, New York, USA) was used for all analyses
A p-value of $<0.05$ was used to indicate significance for the ANOVA analysis, on the other hand $<0.01$ for the correlation analysis.

\section{RESULTS}

Investigations of parameters of microbial soil decomposition in this study revealed a slow rate of biogeochemical processes across the three sites as it was characterised by low soil water and SOM contents, soil enzymes activity, soil phenolics as well as greenhouse gas (GHG) fluxes (Figures 1-5) making these wetlands an excellent medium for moderating the effects of rising climatic temperatures.

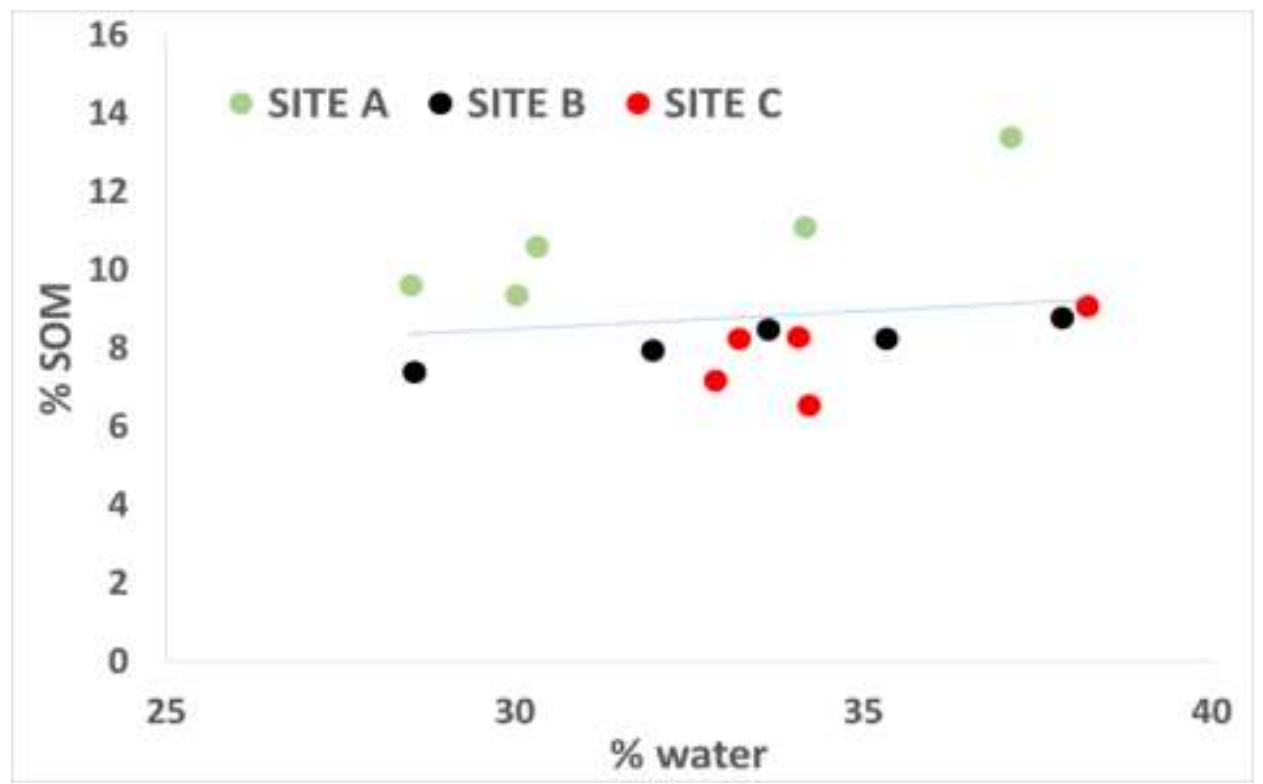

Figure 1: Scatterplot presentation indicating association between $\%$ water and $\%$ soil organic matter across the 3 wetland sites. The trendline shows an exponential relationship

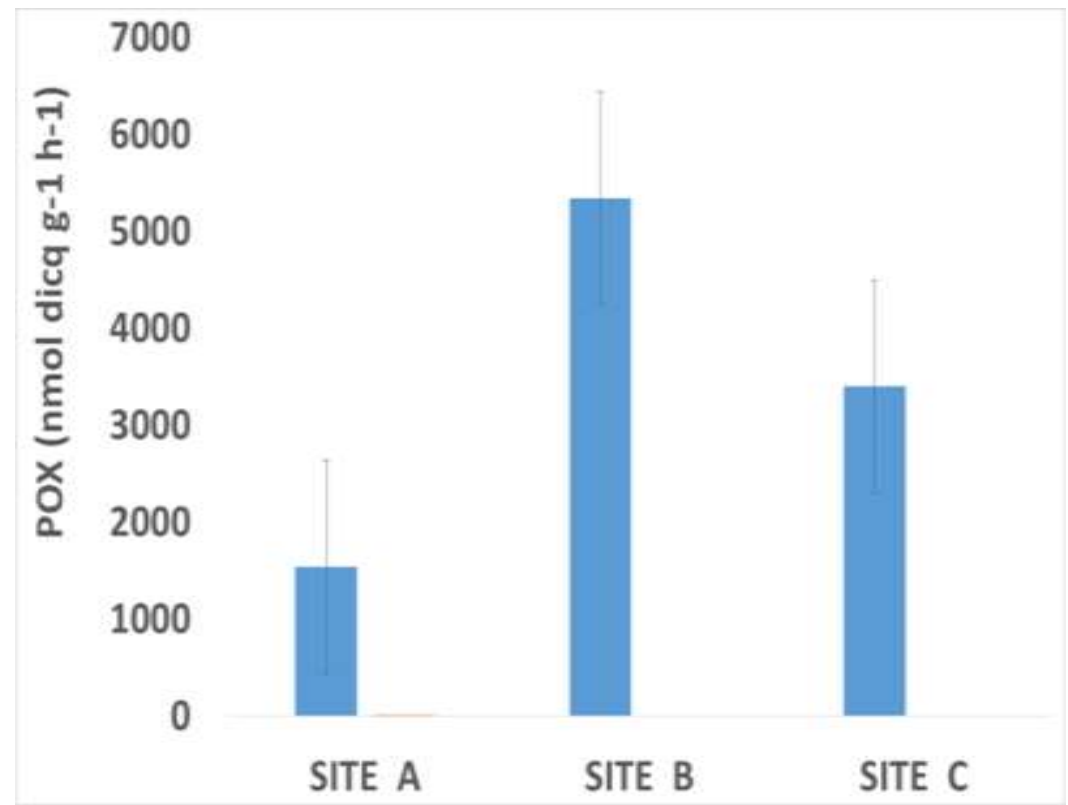


Figure 2: Bar chart indicating average phenol oxidase activity at the three wetland sites $(n=5$, error bars $+S D)$

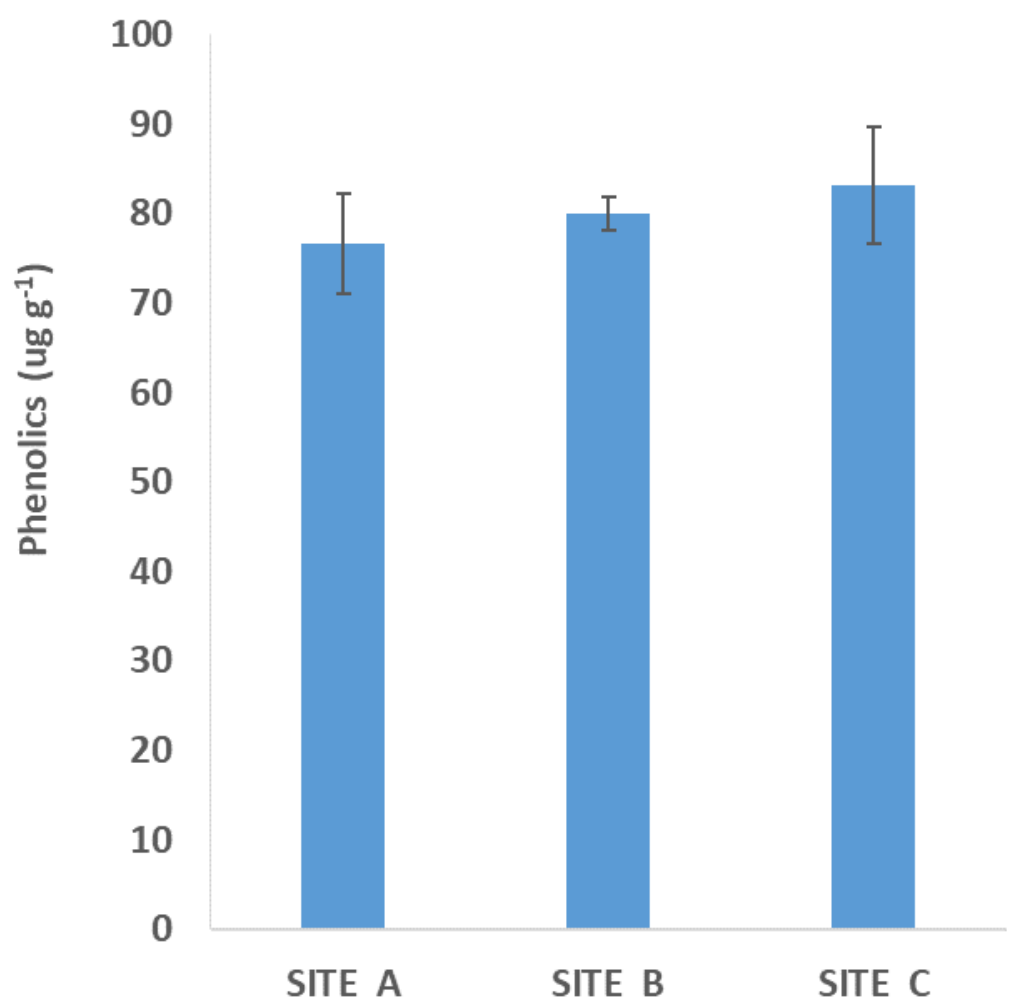

Figure 3: Bar chart showing the mean concentration of soil phenolics in three different wetland sites $(n=5$, error bars + SD)

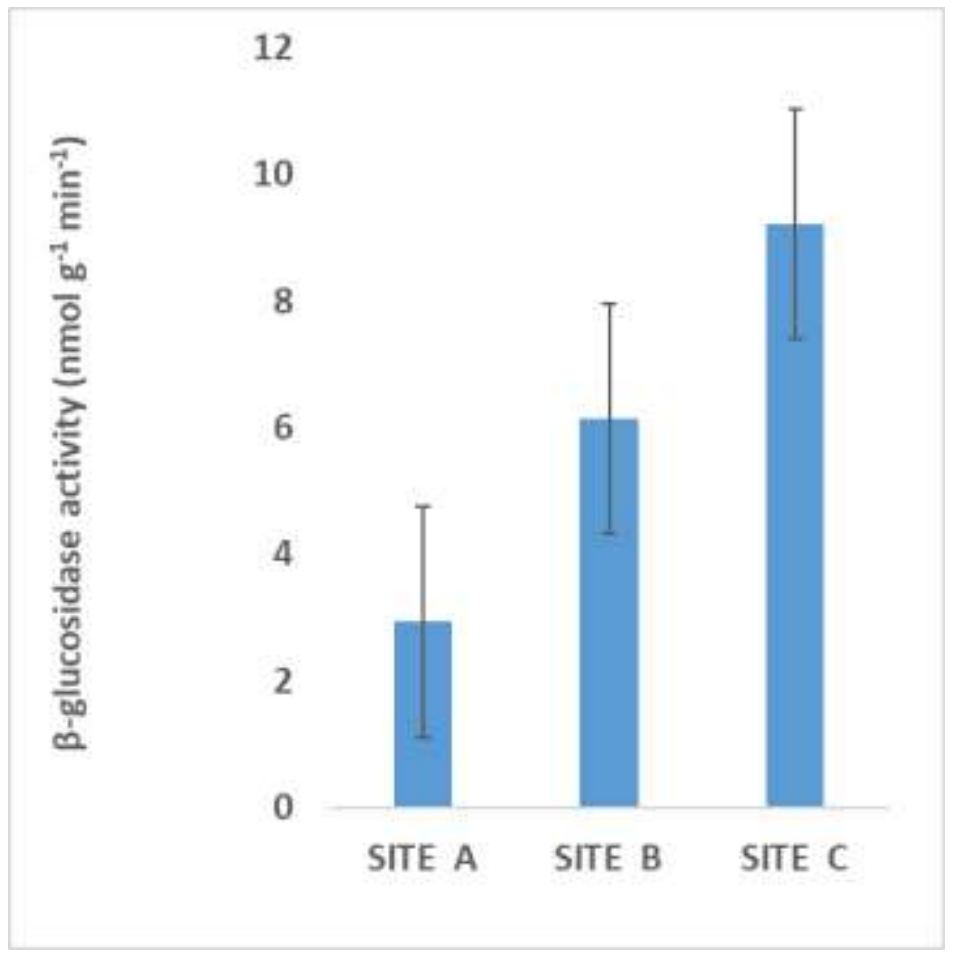

Figure 4: Bar chart of mean hydrolase enzyme activities at the three wetland sites 
$(n=5$, error bars $+S D)$

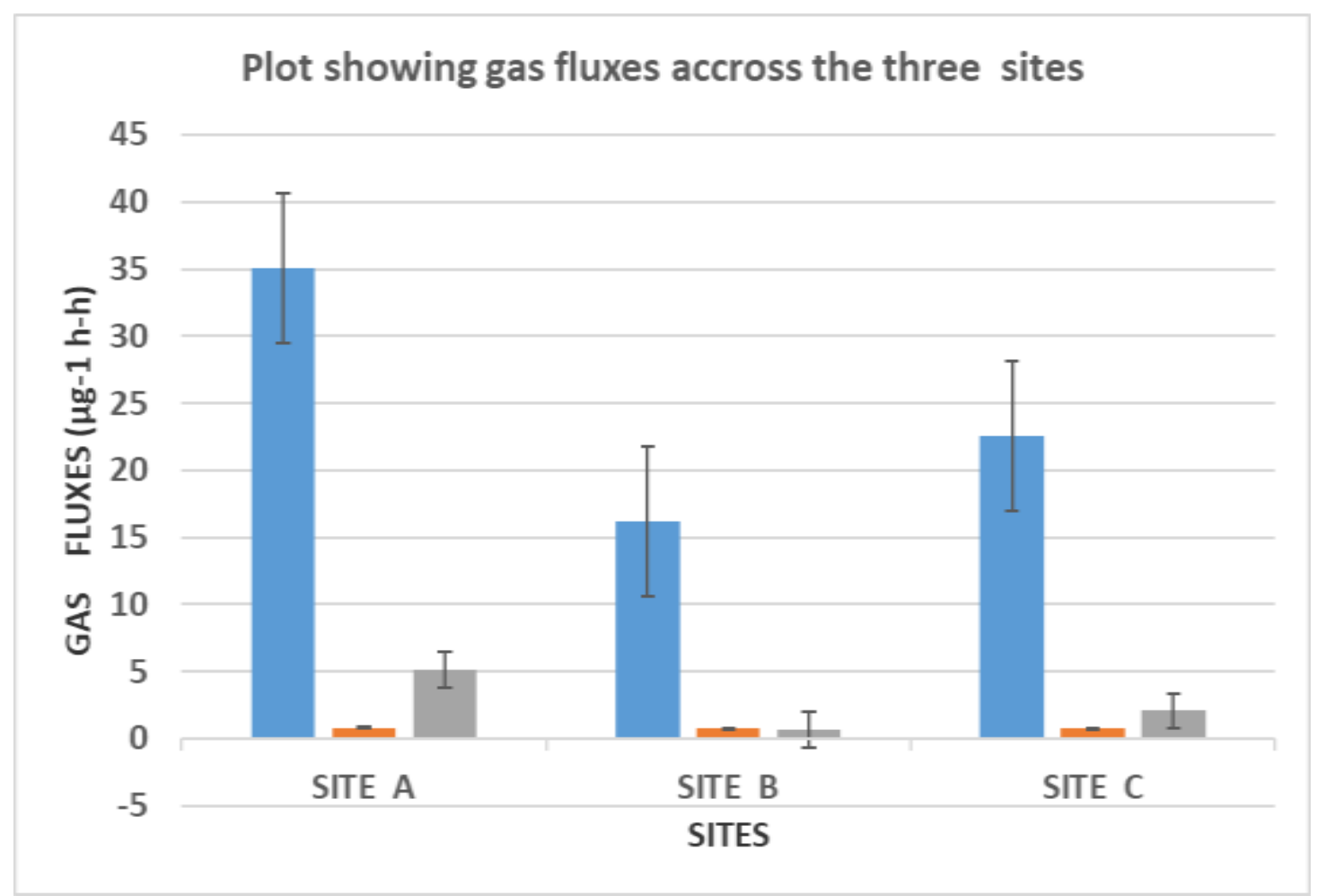

Figure 5: Gas fluxes for $\mathrm{CO}_{2}, \mathrm{CH}_{4}$ and $\mathrm{N}_{2} \mathrm{O}$ across the three sites

\section{DISCUSSION}

Results of analyses revealed that soils from Kpang (Site C) had slightly higher water content $(34.52 \%)$ than Pwomol (site B) $(33.48 \%)$ and Gada biyu (site A) $(32.03 \%)$ while soils from Gada biyu had the highest SOM content of $10.79 \%$ followed by Pwomol (8.15\%). Kpang (site C) had the lowest SOM content of $7.85 \%$ as indicated in Figure 1.0. The differences in both parameters are not statistically significant across the three sites $(p>0.05)$ with a slight positive correlation in the first two sites $(p<0.01)$. High water and organic matter contents in wetland soils indicates a low microbial activity which encourages huge storage of SOM as well as high storage of GHGs over the years. This occurs usually as a result of the anoxic condition in such ecosystems due to low oxygen availability, thereby reducing decomposition and encouraging massive carbon deposit as well enhancing burial of GHGs (Foster et al., 2012, Saraswati et al., 2016).

Soils from site A (Gada biyu) had the lowest Phenol oxidase enzyme activity (1536.56 nmoldicq $\left.\mathrm{g}^{1}{ }^{1} \mathrm{~h}-{ }^{1}\right)$ this was followed by site B (Pwomol) which had slightly more than two-fold activity (3397.31nmoldicq $\mathrm{g}^{1} \mathrm{~h}^{-1}$ ) while site $\mathrm{B}$ had a statistically significantly higher phenol oxidase activity (5340.44nmoldicq $\left.\mathrm{g}_{-}{ }^{1} \mathrm{~h}^{-1}\right)(\mathrm{p}<0.05)$ in comparison with the other two sites (Figure 2). It is also observed that the activity of hydrolases enzyme ( $\beta$-glucosidase) in site A $\left(2.93 \mathrm{nmol} \mathrm{g}^{1}\right.$ min- $\left.{ }^{1}\right)$ is significantly lower than soils from site B $(6.13 \mathrm{nmol}$ $\left.\mathrm{g}^{1}{ }^{1} \mathrm{~min}^{-1}\right)$ while the rate of enzyme activity in site $\mathrm{C}(9.22 \mathrm{nmol}$ $\left.\mathrm{g}^{-1} \mathrm{~min}^{-1}\right)(\mathrm{p}<0.05)$ was a significantly high (Figure 4$)$.
Extracellular enzymes are key to the wetland carbon cycle as they are used by microbes to access nutrients and energy present in complex organic substrates, making enzymes the proximate agents of decomposition.

The concentration of soil phenolics was similar in sites A (76.58 $\left.\mu \mathrm{g} \mathrm{g-}^{1}\right)$ and $\mathrm{B}\left(79.25 \mu \mathrm{g} \mathrm{g}_{-}{ }^{1}\right)$ but site $\mathrm{C}$ had a slightly higher phenolics $\left(83.25 \mu \mathrm{g} \mathrm{g}^{-1}\right)$ these differences are however not statistically significant ( $>0.05$ ) (Figure. 3 ). It is hereby speculated that the presence of phenolic compounds could be the reason in part responsible for low microbial activities across the three sites, hence the low varying activities of hydrolyses which are the main suits of bacterial enzymes involved with the breakdown of organic matter in wetland soils (Pind et al., 1994; Freeman et al., 2004; Saraswati et al., 2016). Figure 5 shows GHGs fluxes across the three sites with $\mathrm{CO}_{2}$ (35.09 ug g- ${ }^{1} \mathrm{~h}^{-1}$ ) and ${ }_{2} \mathrm{O}$ (5.14 ug g-1 h-1) having higher emissions in site A which is statistically significant $(p<0.05)$. There appears to be no significant difference between the rate of emissions of other gases across the three sites ( $p>0.05)$. Therefore, this investigation suggests low emissions of GHGs across the three sites, though soils from site A (Gada biyu) have a significantly higher amount of $\mathrm{CO}_{2}, \mathrm{CH}_{4}$ and $\mathrm{N}_{2} \mathrm{O}$ released into the atmosphere (Figure 3). The release of these GHGs into the atmosphere could produce negative feedback for global warming (ICPC, 2007) and could have a negative consequence on wetlands ecosystem services (Allen et al., 2010; Zhang et al., 2017).

In similar studies involving soils obtained from red, black and white mangrove sites and a salt marsh zone encroached by black mangroves in northern Florida, USA, Dasat (2018) 
established that soil water contents positively correlates with $\mathrm{SOM}$ in all sites and further reported varying rates of low microbial activity and emissions of GHGs notably $\mathrm{CO}_{2}, \mathrm{CH}_{4}$ and $\mathrm{N}_{2} \mathrm{O}$ across the three sites examined.

Forster et al. (2007) investigated the biogeochemistry of some wetland soils in Nigeria's' Niger delta wetlands and revealed that such wetlands could be greatly impacted in response to draining because of warming alternations. These changes could lower the water table, thereby stimulating significant releases of GHGs as a result of an increase in microbial activities which could deplete available soil nutrients (Freeman et al., 1993; Martikainen et al., 1993). Friesen et al. (2018) investigated decomposition in mangrove soils and identified tidal inundation, vegetation types, faunal community, and microbial processes as factors that could influence organic matter accretion in such ecosystems.

Wetland ecosystems globally play a major role in atmospheric carbon seizure, thereby serving as a considerable blue carbon pool with a vast potential to mitigate the effect of climate change (Mcleod et al., 2011; Siikamäki et al., 2013).

In Nigeria, wetlands perform some vitally important hydrological functions such as flood protection, maintain stream flow during the dry season in the semi-arid region of northern Nigeria. Importantly, they also help in regulating surface water quality and volume, as well as in replenishing and sustaining groundwater hence their destruction could trigger more environmental problems.

Unfortunately, Nigeria's wetlands just like others across the globe are diminishing at an alarming rate. In particular, wetlands destruction is affecting water supply and water resources management in various parts of the country. Furthermore, the destruction of the wetlands implies the release of ancient buried carbon into the atmosphere which could further increase the impact of global warming.

The numerous ecosystem services offered by wetlands notwithstanding, these important ecosystems are increasingly coming under stress due to natural and anthropogenic factors. These anthropogenic disturbances if sustained could compromise the carbon sequestration potentials of the Country's wetlands turning them from carbon pools into net sources of GHGs (Alongi, 2011; Everard et al., 2018).

\section{CONCLUSION AND RECOMMENDATIONS}

The biogeochemical activities in the wetland soils across the three sites (Gada biyu, Pwomol and Kpang) investigated were adjudged to be low because of the low rates of decomposition of organic matter and emissions of GHGs. These wetlands could therefore serve as pools of GHGs and could be a vital tool for mitigating the effect of global warming. The loss and degradation of these vital ecosystems could also compromise vital ecosystem services.

Anthropogenically induced degradation of wetland ecosystems in Nigeria could increase the task of water resources management. Thus, the country's wetland resources need to be properly identified and mapped. Moreover, the right legislation and policy framework has to be put in place and enforced to safeguard the remaining wetlands from going into extinction.

\section{REFERENCES}

Adame, M. F. Santini, N. S., Tovilla, C., Vázquez-Lule, A., Castro, L., \& Guevara, M. (2015). Carbon Stocks and Soil Sequestration Rates of Tropical Riverine Wetlands.
Biogeosciences, 1:2, 3805-3818

Adame, M. F., \& Fry, B. (2016). Source and Stability of Soil Carbon in Mangrove and Freshwater Wetlands of the Mexican Pacific Coast. Wetlands Ecology and Management, 24:2, 129137.

Adewumi, S. A. \& Ujoh, F. (2012). Geospatial Analysis of Wetland areas in Ile-ife, Nigeria: Imperative for Sustainable Urbanization. Nigeria Geo. Jn. 8:1, 1-15

Ajibola, M. O. \& OniI, S. A. (2015). Assessing Wetland Services in the Niger Delta, Nigeria. International Jn of Hut and Soc. Sc. 5:1, 268-277.

Allen, C. D., Macalady, A. K., Chenchouni, H., Bachelet, D., McDowell, N., Vennetier, M. \& Cobb, N. (2010). A Global Overview of Drought and Heat-induced Tree Mortality reveals Emerging Climate Change Risks for Forests. Forest Ecology and Management, 259 (4), 660-684.

Alongi, D. M. (2011). Carbon Payments for Mangrove Conservation: Ecosystem constraints and Uncertainties of Sequestration Potential. Environ. Sc. and Policy, 14:4,462-470.

Box, J. D. (1983). Investigation of the Folin-Ciocalteau Phenol Reagent for the Determination of Polyphenolic Substances in Natural Waters. Water Research, 17:5,511-525.

Bridgham, S. D., Megonigal, J. P., Keller, J. K., Bliss, N. B., \&Trettin, C. (2006). The Carbon Balance of North American Wetlands. Wetlands, 26:4, 889-916.

Carius, A. (2017). Lake Chad basin: One long climate catastrophe. https://www.aljazeera.com/indepth/opinion/lakechad-basin-long-climate-catastrophe. Retrieved on 22/83/2020.

Chidi, O.H. \& Ominigbo, O.E. (2010). Climate Change and Coastal Wetlands: Nigeria in Perspective. International Journal of Environmental Issues, 7:2, 216-223

Dasat, G. S. (2018). An Investigation of the Process of Microbial Decomposition and the 'Enzymic latch' Mechanism in Coastal Wetland Ecosystems. Ph.D. Thesis, School of Biological Sciences, Bangor University, Wales-UK.

Dunn, C., Jones, T. G., Girard, A., \& Freeman, C. (2014). Methodologies for Extracellular Enzyme Assays from Wetland soils. Wetlands, 34:1, 9-17.

Everard, M., Sharma, O.P., Vishwakarma, V.K., Khandal, D., Sahu, Y.K., Bhatnagar, R., Singh, J., Kumar, R., Nawab, A., Kumar, A., Kumar, V., Kashyap, A., Pandey, D.N., \& Pinder, A. (2018). Assessing the Feasibility of Integrating Ecosystem-based with Engineered Water Resource Governance and Management for Water Security in Semiarid Landscapes:

A Case Study in the Banas Catchment, Rajasthan, India. Science of the Total Environ. 612, 1249-1265.

Forster, P., Ramaswamy, V., Artaxo, P., Berntsen, T., Betts, R., Fahey, D.W., Haywood, J., Lean, J., Lowe, D. C., Myhre, G., Nganga, J., Prinn, R., Raga, G., Schulz. M., \& Van Dorland, R. 
(2007): Changes in Atmospheric Constituents and Radiative Forcing. In: Climate Change 2007: The Physical Science Basis. Contribution of Working Group I to the Fourth Assessment Report of the Intergovernmental Panel on Climate Change [Solomon, S., Qin, D., Manning, M., Chen, Z., Marquis, M., Averyt, K.B., Tignor, M. \& Miller, H. L. (eds.)]. Cambridge University Press, Cambridge. Pp 129- 234.

Foster, J., Evans, L., Curtin, A., Hill, B., Ronan, M., Wainwright, P., \& O'Donnell, C. (2012). The Role of Wetlands in the Carbon Cycle. Australia National Wetlands Update. Wetlands 14.

Freeman, C., Lock, M. A., \& Reynolds, B. (1993). Climatic Change and the Release of Immobilized Nutrients from Welsh Riparian Wetland Soils. Eco. En, 2:4, 367-373.

Freeman, C., Ostle, N., \& Kang, H. (2001). An Enzymic 'latch on a Global Carbon Store. Nature, 409:6817, 149.

Freeman, C., Ostle, N. J., Fenner, N., \& Kang, H. (2004). A Regulatory Role for Phenol Oxidase During Decomposition in Peatlands. Soil Biology and Biochemistry, 36:10, 1663-1667.

Friesen, S. D., Dunn, C., \& Freeman, C. (2018). Decomposition as a Regulator of Carbon Accretion in Mangroves: A Review. Ecological Engineering, 114, 173-178.

Frogbrook, Z. L., Bell, J., Bradley, R. I., Evans, C., Lark, R. M., Reynolds, B., \& Towers, W. (2009). Quantifying Terrestrial Carbon Stocks: Examining the Spatial Variation in Two Upland areas in the UK and a Comparison to Mapped Estimates of Soil Carbon. Soil use and Management.25:3, 320-332.

IPCC (2007). Summary for Policymakers. Climate Change 2007: Impacts, Adaptation, and Vulnerability. Contribution of Working Group II to the Fourth Assessment Report of the Intergovernmental Panel on Climate Change. Cambridge University Press, Cambridge pp.7-22.

IPCC (2014). Climate Change: 2014: Synthesis Report, in Contribution to Working Groups I, II, and III to the Fifth Assessment Report of the Intergovernmental Panel on Climate Change. Geneva, Switzerland, pp 151.

Kayranli, B., Scholz, M., Mustafa, A., \&Hedmark, Å. (2010). Carbon Storage and Fluxes within Freshwater Wetlands: A critical review. Wetlands, 30:1, 111-124.

Liikanen, A., Huttunen, J. T., Karjalainen, S. M., Heikkinen, K., Väisänen, T. S., Nykänen, H., \& Martikainen, P. J. (2006). Temporal and Seasonal Changes in Greenhouse Gas Emissions from a Constructed Wetland Purifying Peat Mining Runoff Waters. Ecological Engineering, 26:3, 241-251.

Limpens, J., Berendse, F., Blodau, C., Canadell, J. G, Freeman, C., Holden, J., Roulet, N. Rydin, H., \& Schaepman-Strub, G. (2008). Peatlands and the Carbon Cycle: From Local Processes to Global Implications, a Synthesis. Biogeosciences 5:2, 1475 149

Lovelock, C. E., Adame, M. F., Bennion, V., Hayes, M.,
O'Mara, J., Reef, R., \& Santini, N. 31. S. (2014). Contemporary Rates of Carbon Sequestration through Vertical Accretion of Sediments in Mangrove Forests and Saltmarshes of South East Queensland, Australia. Estuaries and Coasts, $37: 3,763-771$.

Malmer, N., Johansson, T., Olsrud, M., \& Christensen, T. R. (2005). Vegetation, Climatic Changes, and Net Carbon Sequestration in a North-Scandinavian Subarctic Mire over 30 years. Global Change Biology, 11:11, 1895-1909.

Mander, Ü., Lõhmus, K., Teiter, S., Mauring, T., Nurk, K., \& Augustin, J. (2008). Gaseous Fluxes in the Nitrogen and Carbon Budgets of Subsurface Flow Constructed Wetlands. Science of the Total Environment, 404:2, 343-353.

Martikainen, P. J., Nykänen, H., Crill, P., \&Silvola, J. (1993). Effect of a Lowered Water Table on Nitrous Oxide Fluxes from Northern Peatlands. Nature, 366:6450, 51-53.

Mcleod, E., Chmura, G. L., Bouillon, S., Salm, R., Björk, M., Duarte, C. M., \& Silliman, B. $\quad$ R. (2011). A Blueprint for Blue Carbon: Toward an Improved Understanding of the Role of Vegetated Coastal Habitats in Sequestering $\mathrm{CO}_{2}$. Frontiers in Ecology and the Environment. 9:10, 552-560.

Mer, J. L., \& Roger, P. (2001). Production, Oxidation, Emission, and Consumption of Methane by Soils: A Review. European Journal of Soil Biology, 37:1, 25-50.

Mitsch, W. J., \&Gosselink, J. G. (2015). Wetlands 5th ed. John Wiley \& Sons. Hoboken, N. J pp 111-215.

Nwankwoala, H. O. (2012). Case Studies on Coastal Wetlands and Water Resources in Nigeria. European Journal of Sustainable Development. 1: 2, 113-126.

Pavlov, A. K., Silyakova, A., Granskog, M. A., Bellerby, R. G. J., Engel, A., Schulz, K. G., \& Brussaard, C. P. D. (2014). Marine CDOM Accumulation During a Coastal Arctic Mesocosm Experiment: No Response to elevated pCO2 levels. Journal of Geophysical Research: Biogeosciences. 119:6, 12161230.

Pind, A., Freeman, C., \& Lock, M. A. (1994). Enzymic Degradation of Phenolic Materials in Peatlands

Measurement of Phenol Oxidase Activity. Plant and Soil, $159: 2,227-231$.

Reddy, K. R., \& DeLaune, R. D. (2008). Biogeochemistry of Wetlands: Science and Applications. CRC Press. Boca Raton, Florida.

Olalekan, E. I., Abimbola, L.M. Saheed, M., \& Damilola, O. A. Wetland Resources of Nigeria: Case Study of the HadejiaNguru Wetlands. Poult Fish WildlSci, 2:2.2-6.

Saraswati, S., Dunn, C., Mitsch, W. J., \& Freeman, C. (2016). Is Peat Accumulation in Mangrove Swamps Influenced by the 'Enzymic latch' Mechanism? Wetlands Ecology and Management. 24:6, 641-650. 
Shange, R., Haugabrooks, E., Ankumah, R., Ibekwe, A. M., Smith, R. C., \& Dowd, S. (2013). Assessing the Diversity and Composition of Bacterial Communities across a Wetland, Transition, Upland Gradient in Macon County Alabama. Diversity, 5:3, 461- 478 .

Siikamaki, J., Sanchirico, J. N., \& Jardine, S. L. (2013). Blue Carbon: Coastal Ecosystems, their Carbon Storage, and Potential for Reducing Emissions. Environment Science and Policy for Sustainable Development. 55:6, 14-29.

Suratman, M. N. (2017). Managing Forest Ecosystems: The Challenge of Climate Change, 2ed. Springer International Publishing. Switzerland. p 452.

Uluocha, N. O. \& Okeke, I. C. (2004). Implications of Wetlands Degradation for Water Resources Management: Lessons from Nigeria. Geo Jn 61: 151-154.

Updegraff, K., Bridgham, S. D., Pastor, J., Weishampel, P., \& Harth, C. (2001). The response of $\mathrm{CO}_{2}$ and $\mathrm{CH}_{2}$ Emissions from Peatlands to Warming and Water Table Manipulation. Ecological Applications. 11:2, 311-326.
Whiting, G. J., \& Chanton, J. P. (2001). Greenhouse Carbon Balance of Wetlands: Methane Emission versus Carbon Sequestration. Tellus B, 53:5, 521-528.

Zaccheaus, O. O. (2011). Multiple Utilizations of Wetlands for Sustainable Food and Water Recycling Production in Nigeria. Sc. Jn of Wat Magmt: 1-9.

Zhang, Z., Xue, Z., Lu, X., Jiang, M., Mao, D., \& Huo, L. (2017). Warming in Spring and Summer Lessons Carbon Accumulation over the Past Century in Temperate Wetlands of northeast China. Wetlands, 37(5), 829-836.

Zheng, C., Wang, G., Liu, J., Song, C., Gao, H., \& Liu, X. (2013). Characterization of the Major Capsid Genes (g23) of T4-type bacteriophages in the Wetlands of northeast China. Microbial Ecology, 65:3, 616-625. 